Гуменюк В. I. доктор філологічних наук, професор Таврійський начіональний університет імені В. І. Вернадського (м. Сімферополь)

\title{
ПАТРІОТИЧНІ МОТИВИ В САТИРИЧНИХ ТВОРАХ ВОЛОДИМИРА ВИННИЧЕНКА
}

У статті підкреслюються, що вболівання В. Винниченка за чистоту, моральну бездоганність людей, які проголошують себе поборниками втілення високих ідеалів, зумовлюють доволі широке звернення автора до сатири у творах патріотичної тематики. Детально проаналізовано під означеним кутом зору оповідання «Малорос-європеєщь» та «Антрепреньор Гаркун-Задунайський».

Ключові слова: Винниченко, рання проза, патріотичні мотиви, сатира.

В статье подчеркивается, что тревога В. Винниченко по поводу чистоты, нравственной безупречности людей, провозглашающих себя радетелями воплочения высоких идеалов, обуславливает довольно широкое обращение автора к сатире в произведениях патриотической тематики. Детально анализируются с этой точки зрения рассказы «Малоросс-европееч» $u$ «Антрепренер Гаркун-Задунайский».

Ключевые слова: Винниченко, ранняя проза, патриотические мотивы, сатира.

The author of the article accents that $V$. Vynnychenko's trouble according the pureness, moral irreproachability of those who declared themselves as the upholders of embodiment of high ideals stipulates rather wide appeal of the writer to the satire in his works of the patriotic topics. Critic analyzes in details from such aspect the short stories "Maloros-European" and "Theatrical enterpriser Harkun-Zadunaysky".

Key words: Vynnychenko, early prose, patriotic motives, satire.

Ти, брате, любиш Русь, Як дім, воли, корови, Я ж не люблю їі

3 надмірної любови.

I. Франко

Серед замовчуваних у радянську епоху визначних постатей української культури одна 3 найвизначніших - Володимир Винниченко (1880-1951), митець і політик, чиє значення в духовному 
пробудженні й самоствердженні народу ще не осягнуте належним чином. Пророче передбачені Лесею Українкою в ії ранній п'єсі «Скульптор» (1898) трагічні колізії художнього життя у ХХ столітті - колізії вибору поміж політикою й цариною краси, колізії вибору між суспільством тиранії й байдужим до мистецтва суспільством зиску - повною мірою торкнулись життєвої й творчої долі В. Винниченка.

Перед Винниченком, сином бідового наймита-чабана, ще в ранньому дитинстві розкрилась потворність суспільної несправедливості. Серед перших дитячих спогадів - знущання поміщика над батьком хлопця (запис у щоденнику від 23 травня 1919 р. [Винниченко 1980: 353]). Бунтарський світогляд і норовливий характер юнака розвиваються в складних умовах провінційної єлисаветградської гімназії, куди батьки за порадою вчительки народної школи віддали напрочуд здібного учня. Атмосфера зневаги до української мови, до бідняцької «білої ворони», якою хлопець почувався серед дітей багатіїв і можновладців, глибоко вражала юну душу. Численні конфлікти з начальством завершуються тим, що він у сьомому класі лишає гімназію і лише згодом завдяки своїй незвичній обдарованості здає екстерном іспити за повний курс гімназії в місті Златополі.

Ситуація дещо повторюється і $з$ набуттям вищої освіти. Виключений 1902 року за революційну діяльність з Київського університету, Винниченко, продовжуючи цю діяльність, серед арештів, мобілізацій, втеч за кордон і т. ін., знаходить у 1905 році час і можливість успішно скласти іспити й здобути офіційне визнання своєї вищої освіти.

Гостре відчуття суспільної несправедливості стало причиною захоплення соціал-демократичним рухом, який набув на той час значного поширення в Європі і Росії і з яким пов'язувалися світлі надії на соціальний прогрес. Проте для Винниченка національне питання завжди було не менш важливе, ніж соціальне. Тому після розколу й реорганізації РУП (Революційної Української Пар- 
тії) він стає одним із керівників УСДРП (Української соціал-демократичної робітничої партії), у програмі якої національні проблеми мали особливу увагу. Врешті він стає одним із лідерів Української національної революції, героїчний ентузіазм і гіркий досвід якої осмислює у своїх творах, художніх і публіцистичних.

Уже у своїх ранніх творах, осмислюючи революційні процеси, митець наголошує на значенні націленості їх учасників на гармонійне розв'язання національних проблем. Про це зокрема йдеться в оповіданні «Роботи!» Суттєве місце в поетиці творів В. Винниченка належить сатиричним засобам виразності. Прикметно, що часто вістря своєї сатири автор спрямовує на потворні явища в українському патріотичному русі, у вияві національної свідомості, очевидно, з тієї причини, що письменникові вболівання за чистоту в цій царині є особливо гострі. Ця авторська позиція має суттєвий стосунок до сповідуваної Винниченком теорії чесності з собою, що розвивається в річищі провідних філософських течій епохи, зокрема болісних шукань Фрідріха Ніцше, спрямованих на духовне очищення суспільства. Винниченко з відчайдушною сміливістю прагне осягти щонайскладніші проблеми, які він спостерігає в революційному, зокрема національно-визвольному русі.

Про творчість В. Винниченка на сьогоднішній день маємо вже немало вагомих досліджень, найбільше 3 них традиційно припадає на ранню прозу автора. Тут можна згадати, наприклад, дисертаційні дослідження Н. М. Алексеєнко [Алесеєнко 2009], О. В. Брайка [Брайко 2002], А. В. Горбань [Горбань 2007], Л. В. Йолкіної [Йолкіна 1997], Н. І. Михальчук [Михальчук 2005]. Проте сатира В. Винниченка, зокрема й сатира його малої прози ще не стала предметом грунтовного дослідження.

Ведучи мову про сатиричну спрямованість патріотичних творів письменника, не можна не згадати його оповідання «Уміркований та щирий», одному з персонажів якого, ультрапатріотові Недоторканому, належить сакраментальна фраза «Геть, чортова кацапня, 3 наших українських тюрмів!» На цю тему й оповідання 
«Малорос-європеєць» (обидва твори вперше опубліковані в збірці «Дрібні оповідання» 1907 року).

Оповідання «Малорос-європеєць» із нещадним сарказмом i глибоким авторським болем викриває людську ницість та захланність, які вміло прикриваються облудними шатами псевдоінтелігентності, зокрема велемовною патріотичною риторикою. У цьому оповіданні, як і в деяких інших творах автора, своєрідно подається образ інтелігентного оповідача, котрий $є$ водночас і учасником подій. Тут це вчитель, що їде в пошуках заробітку до одного провінційного пана, рекомендованого йому як людина відома своїм «демократизмом, українством, лібералізмом», їде, аби стати репетитором «паненяти». Мова оповідача відзначається тонкою іронією (у тім числі й самоіронією), яка непомітно переходить у їдкий сарказм, головним об'єктом якого є «ліберальний» пан з промовистим прізвищем Коростенко, а врешті набуває стримано трагічного звучання.

Важливу функцію в образній системі твору виконує заявлена на початку яскрава видовищна деталь, яка вражаюче обігрується у фіналі. При в'їзді оповідача в село його зустрічало весілля - «На воротях стирчало гілля, обвішане червоними стьожками й перев 'язане хусткою» [Винниченко 1989: 446]. У народному весільному обряді оздоблене гілля символізує щастя. Його несуть від дому молодої до дому молодого, з ним заходять до осель найшановніших людей.

Основна увага в оповіданні звертається на поміщика Коростенка, самозакоханого самодура, що видає себе за неймовірно передову та прогресивну особистість. Динамічні портретні штрихи підкреслюють цю самозакоханість і байдужість до всього, що безпосередньо не стосується його власної персони: «Я був голодний, $i$ хотілось остатись самому: хотілось вмитись, роздягтись $і$ хоч трохи спочити від драбинчастого возика. Але Коростенко, видно, й не думав покидати мене. I я вже з неприязню дивився на товсту його шию, на англійські бакенбарди й розчісану надвоє, як у лакеїв, голову» [ Винниченко 1989: 449]. 
Пан заходився без упину показувати учителю своє машинізоване «європеїзоване» господарство, зовсім не зважаючи на втому, на голод і душевний стан здороженого прибульця: «...мені так схотілося їсти, що я став позіхать $i$, щоб не образити його, мусив ковтати зівки... Балакав він мовою якоюсь кумедною, книжною, скоріше російською, перекладаючи тільки московські слова на украйнські. Але я майже нічого не чув $і$ дедалі то все більш $і$ більш втрачав надію колись скінчити огляд иих сіялок, віялок, жаток, плугів, телефонів, електричних дзвінків, конюшень, амбарів, водопроводів, водокачок, молотилень, маслобоєнь, собачих будок» [Винниченко 1989: 449-450].

Чіткими, психологічно проникливими штрихами раз-у-раз проймають невгамовну Коростенкову велемовність то запитання до лакея, то звертання до гостя, пов'язані з селянськими зворушеннями як у всій країні, так і конкретно в його власному маєтку. У цих штрихах проглядається справжня сутність персонажа, яка цілком явно розкривається у фіналі. Забачивши валку селян, що наближались до панського обійстя, Коростенко миттю видобув давно наготовлений кулемет і зі словами «Не подходи!.. Убью! Всех убью-у.» [Винниченко 1989: 455] (куди й поділась його показна прихильність до української мови) розпочав стрілянину. Невдовзі з'ясовується моторошна іронія ситуації. То йшли не бунтарі, а сільське весілля до пана за традиційним благословенням, яке цього разу виявилось аж ніяк не традиційним: «Вбито було одного, того якраз, що ніс гілля з червоними хустками й стьожками, а ранено дві баби йхлопчика» [Винниченко 1989: 456].

«Позиція письменника, - зазначає О. Г. Ковальчук, - однозначна: святій справі національного відродження, плеканню таких високих почуттів, як національна гордість і честь, завжди завдають найбільшої шкоди ті підлі, мізерні люди, що задоволення потреб власного черева намагаються видати за невтомну патріотичну діяльність» [Ковальчук 1991]. Порушуючи національні й інші суспільні проблеми, письменник разом $з$ тим ставить перед 
собою значно ширші завдання, художньо осягаючи злети й падіння людської душі.

Глибоким істинним патріотизмом, уболіванням автора за долю української культури пройнятий один з найбільш популярних творів автора - оповідання «Антерпреньор Гаркун-Задунайський» (1903), у якому винесене в заголовок наймення головного персонажа в процесі розгортання сюжету зазнає цілковитого художнього переосмислення - від піднесено-патетичного звучання переходить на сумовито-зневажливе (дещо подібно до франківського Бессервіссера). Цей гучний псевдонім, прибраний для себе власником та учасником провінційної театральної трупи, мимоволі асоціюється з іменем видатного українського співака й композитора Семена Гулака-Артемовського, автора опери «Запорожець за Дунаєм», і свідчить про високі амбіції Винниченкового персонажа, який ставить себе врівень із іншими знаменитостями, зокрема визначним режисером Марком Кропивницьким.

Своєрідним контрапунктом до сатирично обарвлених картин, віссю яких є постать провінційного театрального діяча, виступає тут образ оповідача, який надає сумовитого відтінку цим картинам. Тож важко погодитись 3 Лесею Українкою, яка писала, що провінційне театральне життя у Винниченковому творі «взяте виключно з комічної точки зору» [Винниченко 1989: 246].

Персонаж, від імені якого ведеться оповідь, постає перед нами людиною інтелігентною, спостережливою, тактовною. Його інтелігентність не показна, а глибоко органічна, пов'язана 3 широтою світовідчуття. «Занесла мене лиха година в невеличкий повітовий город $N \gg$ - починає він у стилі народного оповідання і тут же, аби докладно вияснити слухачеві (читачеві) суть речі, згадує, як, вийшовши на залізничній станції, їхав далі до міста на драбинчастому візку. Як це часто буває у творах В. Винниченка, спочатку подається лаконічний краєвид, покликаний відтінити подальші події. Але «потрусювання, яким починав діймати все більш та більи драбинчастий візок», хоч і не завадило персонажеві милува- 
тися довкіллям, все ж виступило в ролі певного дисонансу, натяку на ту дисгармонію, що розкриється пізніше. Тим часом пейзажні картини, так само, як і благодушна постать їздового, виявились вельми суголосними мрійному станові оповідача: «Все минуле десь ховалось у якомусь тумані, $і$ будучність ласкаво й привітно всміхалася, як всміхався мій візник до високих і пишних хлібів» [Винниченко 1989 :. 90]. В уяві оповідача постає «гостініца Малоросія», що чекає на нього в місті («будиночок чистенький, гарненький; коло його садочок, квітки, метелики і таке інше»), та зустріч $з$ одним із іï мешканців - добродієм Гаркуном-Задунайським, антрепренером місцевої театральної трупи, у якій герой сподівається знайти для себе роботу. Очевидно, оповідач - це студент або й випускник університету, котрий вирішив покинути гамірливе й задушливе велике місто та на тихій провінції зайнятись культурною діяльністю. Слава українського театру корифеїв, який на зламі століть уже не був у розповні творчих сил, а все ж надихав багатьох на самовіддане служіння рідній культурі, могла прихилити до мистецтва й Винниченкового героя (недаремне у творі згадується ім'я Кропивницького).

I от - перша зустріч оповідача $з$ реальною дійсністю. Перше розчарування. «Гостініца Малоросія», яка не знати чому так називається, - то цілковитий контраст 3 тими «квітками й метеликами», які щойно постали в уяві героя. У змалюванні ї̈ Винниченко користується характерними для його стилю відверто-натуралістичними штрихами. Цей натуралізм уже настільки виразний, що не втрачаючи своєї означеності, часом навіть сягає сюрреалістичних граней. Ось як, скажімо, описано картину, яка відкрилась після того, як візникові не без зусиль вдалося відчинити двері: «Серед чорного брудного невеличкого коридорчика в самих різних позах лежало декілька великих і малих жидків. Ноги одного були під самим носом у другого, третій утнувся четвертому в живіт головою $i$ сягав коліном в спину п'ятому; носи мішалися з пальчями, руки з ногами; брудні подушки, аж блискучі від сала, шо назбиралося за 
немалий, мабуть, час, лежали десь аж біля порога. Повітря... Дядько мій тільки крутнув носом...» [Винниченко 1989: 93]. Можна, мабуть, сказати, що це якоюсь мірою передчуття мистецьких особливостей «Герніки». У такому ж дусі відтворено зустріч з господарем «гостініци» - вкрай улесливим Лейзером і поселення в «самий луччий номер!»

У другій частині оповідання відбувається "сакраментальна» зустріч з Гаркуном-Задунайським, уже саме прізвище якого може дати певне уявлення про цього персонажа - людину безмірних амбіцій, хворого марнолюбства, схильну до різких широких жестів і громових інтонацій, наскрізь просякнуту махровою театральщиною, яка в житті виявляється ще реальнішою, ніж на сцені. Гаркун славить себе й свою «ну античную просто» трупу, демагогічно заявляє про набитий глядачами зал, про творчі й фінансові успіхи, які не снилися навіть Кропивницькому, хоч насправді, як виявляється згодом, його незугарні вистави йдуть у майже порожньому залі, який і залом назвати важко (це якась загорожа з повіткою, де кілька рядків прибитих до колодок шорстких дощок). Влучними сатиричними штрихами, що межують 3 фантасмагорично-гротескними, передано його зовнішність - «B синій суконній чумариі, в таких же штанях в чоботи, з сивою шапкою в одній ручі (i то серед пекучого літа!) і якоюсь ломакою в другій, постать ия нагадувала... якогось гайдамаку»; «Проти волі задивившись на його великі жовті зуби, я переніс погляд на личе і став роздивлятись його. Воно було кругле, скрізь виголене $і$ страшно червоне; здавалось, добродій Гаркун колись дуже розсердився, почервонів та так $і$ застиг навіки червоний». Підкреслюється велемовність цього персонажа («розмова аж кипіла у нас, чи то пак у його»), його любов до псевдовчених слів на кшталт «індиферентизм», його повсякчасне позерство («Він знов махнув рукою і картинно замислився. Ніс його виразно красувавсь на бруднім фоні стіни, очі мутно дивились кудись під стілець...»), не оминаються й такі промовисті деталі, як палець «з чорненькою смужкою на кінці нігтя» [Винниченко 1989: 96-99]. 
I все ж за всієї яскравості прикметних ознак провінційного служителя Мельпомени в цій постаті знаходяться нюанси, які свідчать про драматичну складність, психологічну неоднозначність натури персонажа, хай, може, й спотворені, але колись привабливі риси його єства, хоч вони виявляються здебільшого таким чином, що лише підкреслюють сатиричну виразність образу. Гаркун людина, не позбавлена кмітливості, раціональної розсудливості, за всієї схильності до демагогічної самореклами він уміє розгледіти й оцінити співрозмовника, знайти підхід до нього. От і в сцені зустрічі з оповідачем, який, звичайно, волів би після цієї зустрічі більше ніколи з Гаркуном не стрічатися, «антрепреньор» таки зумів розжалобити хлопця, розвіяти його «індиферентизм» і умовити працювати в трупі суфлером: «Він навіть схопив мого гудзика $i$ почав, невідомо для чого, крутить його на всі боки. Я глянув на гудзика, на пальиі, з яких один був з понівеченим нігтем, і мені чогось жаль його стало». Про те, що всупереч показній театральності Гаркун вміє реально оцінювати обставини, свідчить і епізод, коли касирка звернулась до нього з резонним запитанням, чи варто починати виставу, коли в касі всього «6 р. 73 коп.» Гаркун (мовляв, справа не в грошах, а в натхненні) так накинувся зі своєю патетикою на касирку, що ту «неначе вітром змело». Коли ж примадонна Галіна (вона й дружина «антрепреньора») з-за перегородки, що відділяла жіночу «уборну» від чоловічої, заявила, що грати за такі гроші - «ідіотство», з персонажем сталася несподівана метаморфоза: «Тут, я думав, добродій Гаркун не витримає такої наруги над своїм "настроєнім" і покаже, як можна так "індиферентно "відноситись до "іскуства, котре єсть така штука, що "... Але вийшло інше... Добродій Гаркун тільки лагідно відповів: - Ну, а що ж робить?.. Треба... Може, хоч музикантам стане... Та, може, ще й публіка надійде» [Винниченко 1989: 118].

Цілком можливо, що в оповідачеві Гаркун відчув чистоту, за якою стужились якісь закапелки його душі, згадав у зв'язку з ним якісь свої молодечі нездійснені мрії. Тому й так швидко запросив 
його до себе на роботу, тому й намагався при ньому незграбно нагадувати акторам про дисципліну в театрі, де репетиції й вистави починались на півтори-дві години пізніше, ніж належало, тому й закликав його до себе на обід, тому й з такою настирливістю, хай і безрезультатною, намагався у фінальній сцені прилучити до п'яної гульні артистів у брудній «гостініце». За всієї сатиричної виразності постать Гаркуна не позбавлена психологічної переконливості, яка суттєво посилює викривальну суть образу.

Постаті акторів (вередливої примадонни Галіни, веселих антиподів - Гонти й Залізняка, чиї прибрані імена звучать не менш претензійно, ніж антрепренерове, смирного й тихого подружжя Петренків), процес репетиції, підготовки до вистави й сама вистава, що через самовпевнену неуважність виконавця головної ролі Гаркуна - $з$ тріском провалилась, - усе це передано з бездоганним знанням акторської психології і далеко не завжди привабливих особливостей закулісної театральної атмосфери, 3 майстерним обігруванням численних колоритних подробиць, 3 яких постає сатирична картина театральної й не лише театральної рутини.

Бачимо, як заявлене в заголовку патетичне звучання наймення головного персонажа поступово все більше знижується. Цьому зниженню сприяє конструкція цього композитного наймення. Перша, коротка, його частина - Гаркун, яка попервах видається завуальованою милозвучною розлогістю другої частини - Задунайський, - поступово привертає основну увагу. Саме до оперування нею переходить оповідач. «Добродій Гаркун» - так після знайомства він переважно називає персонажа, вкладаючи в слово «добродій» іронічний зміст. Перша частина наймення театрального діяча асоціюється швидше не зі сценічною майстерністю, а 3 фальшивою патетикою, що у свою чергу викликане тим, що таке ім'я мало личить артистові і може сприйматись як якесь прізвисько зоонімного характеру. Переключенню емоційно-оцінювальних регістрів сприяє й активне функціонування у творі інших назв персонажа поруч з основним. «Пейоратив Васька, - відзначає дослід- 
ник Г. Лукаш, $-\epsilon$ заключним в антропонімічному ряді іменувань антрепренера - артиста з гучним артистичним прізвищем: Гаркун-Задунайський - добродій Гаркун - Василій (Василь) Олександрович - Васька. За допомогою згрубілої іменної форми героїня (примадонна Галіна) висловлює в одному із епізодів обурення, принижуючи пишноту прізвища свого чоловіка» [Лукаш 1992: 125].

Увиразнює порожньо-претензійну пишноту наймення персонажа ще одна художня обставина. В оповіданні, по суті, є два головні герої. Поруч з провінційним служителем Мельпомени в ненав'язливому йому протиставленні виведений безіменний оповідач. І саме його безіменність виявляється не менш промовистою, ніж гучно-розложисте ім'я горе-артиста. Так само промовистий і безіменний топонім, назва місцевості, де відбувається дія, - місто N. Тут дається взнаки характерна для Винниченка поетика контрастів, яка увиразнює глибинний драматизм твору.

Окремо варто зупинитись на п’єсі, що ії спочатку представляє претензійна афіша, у якій прізвище Гаркуна-Задунайського двічі виведене великими літерами. Це твір з промовистою назвою «Люте серце, або ж Чотири смерті разом. Драма на 4 дії Сьогобережного», твір, узятий Гаркуном до постановки, очевидно, з тієї причини, що за його переконанням, широка публіка через свій «індиферентизм» не сприймає «n'єс передових, так сказать е... е... з.. ну, з направлєнієм». Зміст п'єси оповідач змушений переказати, аби стало зрозуміло, яким чином Гаркун провалив виставу - з'явився несподівано на сцені тоді, коли його герой ще мав тривалий час перебувати за вбивство суперника в ув'язненні на Сахаліні. Цей переказ нищівна сатира на низькопробну драму про ідилічне кохання, якому не судилось увінчатися одруженням через підступність не байдужого до нареченої лиходія. Говорячи про таку п'єсу, Винниченко випускає влучні саркастичні стріли в напрямкові живучих драморобних шаблонів: «...що б то була за украйнська драма, якби кожному дозволялось женитись»; «ви знаєте, який це Гаврило, його в кожній украӥнській драмі можна бачить. Злий, єхидний, поганий, 
гидкий...» Прикметно, що вбивство суперника відбувається неодмінно на вечорницях, слідом іде серія наступних смертей. Звертається увага і на неодмінний шаблон, що побутує при постановці таких п'єс - розбавлення супердраматичних подій сентиментальними дивертисментними співами: «Вже пройшло з половину дії. Уже Маруся проспівала Шевченкове "Коли розлучаються двоє" (музика Лисенка, иіна 30 коп.), уже й наготовилась співати "Ми заспівали, розійшлись", гарненько утерши сльози...» (очевидно, усе, що співалося в таких виставах, приписувалося Шевченкові) [Винниченко 1989: 121].

Аналізоване оповідання досить швидко стало одним з найбільш популярних творів В. Винниченка. «В Гаркуні-Задунайському, що стає з часу свого появлення збірною назвою для малоросійської театральної "халтури", - пише О. Гермайзе, - пізнано було не тільки наму глуху провінцію з ї п'яними "культурними" діячами та невизнаними талантами, не тільки від громадянства відірвану малоросійщину, але елементи творчих прийомів та театрального побуту пізнано було $і$ в оточенні, що рівнем вище стояло за трупу класичного Гаркуна. Сатира Винниченкова мусіла спричинитися до оздоровлення атмосфери, що оточувала живе діло украйнського театру» [Гермайзе 1929: ХІІІ]. Слід додати, що не тільки театру. За розгорнутими в «Антрепреньорі...» колоритними картинами провінційної театральної рутини вгадується гостра тривога Винниченка за долю української культури. Оповідання, без сумніву, симптоматичне й з огляду на те, що в час його написання Винниченко приглядався до становища тодішнього українського театру саме як майбутній драматург. I значною мірою в рішучій полеміці 3 подібною практикою 3'являються його перші п’єси.

Сатиричні риси виразно даються взнаки і в інших торах автора, пройнятих його щирими вболіваннями за справжню, а не показну високість людських помислів і поривань. Це можна сказати зокрема про такі п’єси, як «Співочі товариства», «Молода 
кров», «Пророк», про соціально-філософські романи (в аспекті означеної теми показовий, наприклад, такий як «Поклади золота»). Як бачимо, тут маємо широке поле для досліджень.

\section{БІБЛІОГРАФІЯ}

Алексеєнко 2009 - Алексеєнко Н. М. Стильові особливості малої прози Володимира Винниченка та проблема художнього напрямку : автореф. дис. ... канд. філол. наук / Алексеєнко Наталія Михайлівна ; Київський нац. університет ім. Т. Шевченка. - К., 2009. - 20 с.

Брайко 2002 - Брайко О. В. Поетика прози Володимира Винниченка 1900-1910-х років : автореф. дис. ... канд. філол. наук / Олександр Валентинович Брайко ; Київський нац. університет ім. Т. Шевченка. - К., 2002. - 18 с.

Винниченко 1980 - Винниченко В. Щоденник. - Т. 1: 1911-1920 / ред., вст. ст. і прим Г. Костюка. - Едмонтон ; Нью-Йорк : Видання Канадського Інституту Українських Студій, 1980. - 500 с.

Винниченко 1989 - Винниченко В. Краса і сила : Повісті та оповідання / Володимир Винниченко. - К. : Дніпро, 1989. - 752 с.

Гермайзе 1929 - Гермайзе О. Рання творчість Винниченкова на тлі громадського життя / Осип Гермайзе // Винниченко В. Вибрані твори / Володимир Винниченко. - Харків : Книгоспілка, 1929. - 238 с.

Горбань 2007 - Горбань А. В. Мала проза В. Винниченка у світлі авторської суб'єктивності : автореф. дис. ... канд. філол. наук / Анфіса Василівна Горбань ; НАН України, Інститут л-ри ім. Т. Г. Шевченка. - К., 2007. - 20 с.

Йолкіна 1997 - Йолкіна Л. В. Мала проза Володимира Винниченка (до характеристики індивідуального стилю) : автореф. дис. ... канд. філол. наук / Лариса Віссаріонівна Йолкіна ; Український державний пед. університет ім. М. П. Драгоманова. - К., 1997. - 22 с.

Ковальчук 1991 - Ковальчук О. Г. Ранні оповідання Володимира Винниченка / О. Г. Ковальчук // Українська мова і література в школі. - 1991. - № 1. C. $35-36$.

Лукаш 1992 - Лукаш Г. Взаємодія української та російської знімної лексики в мові творів В. К. Винниченка / Г. Лукаш // Літературна ономастика української та російської мов : взаємодія, взаємозв'язки. -К., 1992.

Михальчук 2005 - Михальчук Н. І. Мала проза Володимира Винниченка : від метафізичного до естетичного : автореф. дис. ... канд. філол. наук / Ніна Іванівна Михальчук ; Київський нац. університет ім. Т. Шевченка. - К., 2005. $-22 \mathrm{c}$.

Українка 1998 - Леся Українка [Винниченко] / Леся Українка // Історія української літературної критики та літературознавства : хрестоматія : у 3 кн. Кн. 2 / упор. П. М. Федченко. - К. : Либідь, 1998. - С. 319-337. 